\section{GEOGRAFÍAS DEL DESPLAZAMIENTO EN EL URBANISMO DE AMÉRICA LATINA}

\author{
Georgia Alexandri*, Sara González** y Stuart \\ Hodkinson***
}

La economía política global del siglo XXI se enfrenta por todo el mundo con "la aparición de nuevas lógicas de expulsión”. Estas lógicas son extremadamente variadas: desde la expulsión de trabajadores con bajos ingresos o en paro de sus puestos de trabajo seguros y sus derechos de seguridad social en el mundo occidental2 ; el desplazamiento forzoso de comunidades agrícolas en el Sur Global a través

* España. Investigadora post-doctoral Juan de la Cierva, Departamento de Ciencia Política y Relaciones Internacionales, Universidad Autónoma de Madrid. Correo electrónico: georgia. alexandri@uam.es

* Inglaterra. Profesora asociada Escuela de Geografía Universidad de Leeds. Correo electrónico: s.gonzalez@leeds.ac.uk.

** Inglaterra. Profesor asociado Escuela de Geografía Universidad de Leeds. Correo electrónico: s.n.hodkinson@leeds.ac.uk

1 Sassen, 2014, p. 1.

2 Andreß y Lohmann, 2008.

\section{LOCATING DISPLACEMENT IN LATIN AMERICAN URBANISM}

Georgia Alexandri*, Sara González** and Stuart Hodkinson***

The global political economy of the twentyfirst century is everywhere confronted with "the emergence of new logics of expulsion". These logics range from the expulsion of low-income or unemployed workers from secure jobs and collectivist welfare support in the West ${ }^{2}$; the displacement of farming communities in the global south through land grabs by foreign governments

\footnotetext{
* Spain. Juan de la Cierva Post-doctoral researcher, departamento de Ciencia Política y Relaciones Internacionales, Universidad Autónoma de Madrid, Contested Cities node Madrid. Email address: georgia.alexandri@uam.es

* England. Associate Professor, School of Geography, University of Leeds, Contested Cities node Leeds. Email address: s.gonzalez@leeds.ac.uk

*** England. Associate Professor, School of Geography, University of Leeds, Contested Cities node Leeds. Email address: s.n.Hodkinson@leeds.ac.uk

1 Sassen, 2014, p. 1.

2 Andreß and Lohmann, 2008.
} 
de la expropiación de sus tierras por gobiernos y corporaciones para la explotación especulativa de cultivos industriales ${ }^{3}$; y el desalojo forzoso de personas de sus hogares -ya sea de alquiler, en propiedad u ocupados-algo que está en aumento en todo el mundo ${ }^{4}$. América Latina, por supuesto, no es ajena a esta lógica de expulsión, de hecho su historia está llena de episodios de despojo de las poblaciones indígenas, condición sine qua non de la colonización europea y del desarrollo capitalista post-colonial ${ }^{5}$. En las últimas tres décadas, sin embargo, las ciudades de América Latina han experimentado sus propias nuevas lógicas de expulsión imbricadas en la reestructuración del espacio urbano. En contraste con épocas anteriores, cuando la transformación urbana en América Latina tomó principalmente la forma de expansión urbana hacia la periferia suburbana de manera centrífuga ${ }^{6}$, una serie de procesos políticos y económicos urbanos asociados a la gentrificación han reafirmado el papel de los centros históricos en el contexto de una amplia re-articulación socio-espacial de áreas centrales, semi-periféricas o peri centrales ${ }^{7}$.

Si bien reconocemos la naturaleza controvertida de la gentrificación tanto como concepto teórico y como realidad empírica en los debates

Hall, 2013.

Kothari, 2015.

Por ejemplo, véase Cabrera Pacheco, en prensa.

Herzog, 2015.

Hidalgo y Janoschka, 2014. and corporations seeking to speculatively profit from industrial crop production ${ }^{3}$; and the forcible eviction of people from their homes -whether rented, owned or occupied-which is on the rise across the world ${ }^{4}$. Latin America is, of course, no stranger to the logics of expulsion, its history replete with episodes of violent dislocation and dispossession of indigenous populations that were the sine qua non of European colonisation and post-colonial capitalist development ${ }^{5}$.Over the past three decades, however, Latin American cities have experienced their own new logics of expulsion imbricated in the restructuring of urban space. In contrast to previous eras when urban transformation in Latin America mainly took the form of expansion or urban sprawl to the suburban periphery in a centrifugal fashion ${ }^{6}$, a series of urban political and economic processes associated with gentrification have reasserted the role of historic centres amid a wider socio-spatial re-articulation across central, semi-peripheral or peri-central areas ${ }^{\top}$.

While acknowledging the contested nature of gentrification both as a concept and empirical reality in Latin American debates, we follow

Hall, 2013.

Kothari, 2015.

For example, see Cabrera Pacheco, in press.

Herzog, 2015.

Hidalgo and Janoschka, 2014 
latinoamericanos, nos basamos en la amplia definición de $\mathrm{Clark}^{8}$ donde la gentrificación se entiende como proceso fundamentalmente de clase que supone un "cambio en la población de usuarios del suelo de tal manera que los nuevos usuarios son de un estatus socioeconómico más alto que los usuarios anteriores, junto con un cambio asociado en el entorno construido a través de una reinversión en capital fijo". O, para decirlo de otro modo, en las palabras de Neil Smith, la gentrificación es "un vehículo para la transformación de zonas enteras en nuevos paisajes que abren el camino a una refundición urbana exhaustiva impuesta por intereses de clase (...) nuevos complejos enteros de recreación, consumo, producción, y ocio, así como de vivienda (...) [que] entrelaza los mercados financieros globales, junto con grandes y medianos promotores inmobiliarios, pequeños comerciantes y agentes de la propiedad con minoristas de marca, todo ello lubricado por los gobiernos municipales y locales para quienes los beneficios sociales ahora derivan del mercado más que de su regulación". Por lo tanto, la gentrificación puede implicar tanto suelo vacante como ocupado -ya que estos procesos tienen lugar con frecuencia durante largos períodos -pero siempre implica el desplazamiento y el despojo de una forma $u$ otra ${ }^{10}$.

8 Clark, 2005, p. 258.

9 Smith, 2002, p. 443.

10 Slater, 2009.
Clark's ${ }^{8}$ broad definition of a class-based process of "change in the population of land-users such that the new users are of a higher socio-economic status than the previous users, together with an associated change in the built environment through a reinvestment in fixed capital". Or, to put it another way, in the words of the late Neil Smith, gentrification is "a vehicle for transforming whole areas into new landscape complexes that pioneer a comprehensive class-inflected urban remake (...) whole new complexes of recreation, consumption, production, and pleasure, as well as residence(...) [that] weaves global financial markets together with large- and medium-sized real-estate developers, local merchants, and property agents with brandname retailers, all lubricated by city and local governments for whom beneficent social outcomes are now assumed to derive from the market rather than from its regulation".Gentrification can therefore also involve vacant as well as occupied land-because these processes often take place over a long period- but always involves displacement and dispossession in some shape or form ${ }^{10}$.

Understanding the rise of gentrification and displacement in Latin American cities is impossible without an appreciation of how

\footnotetext{
Clark, 2005, p. 258.

Smith, 2002, p. 443.
}

10 Slater, 2009. 
Para entender el aumento de la importancia de fenómenos de gentrificación y desplazamiento en las ciudades de América Latina tenemos que considerar cómo el "neoliberalismo planetario"11 se ha afianzado aquí. En las últimas décadas, y a pesar de los gobiernos de izquierdas más recientes, los gobiernos de América Latina han desmontado las protecciones sociales que se habían ido creando vis a vis las fuerzas del mercado y han ido desplegando procesos de privatización, desregulación y reformas de liberalización, a menudo impuestas por las tramas institucionales relacionadas con los programas de ajuste estructurales del FMI y el Banco Mundial que condicionaron el acceso a fondos de ayuda y deuda al proyecto de la globalización ${ }^{12}$. En la escala urbana, el neoliberalismo ha desplegado un proceso de "creación destructiva" para recuperar las ciudades como lugares centrales en la acumulación de capital financiero y el consumo de élite a través de la privatización de servicios públicos e infraestructura, mega proyectos urbanos y proyectos de urbanización cerradas, deliberada periferalización de los complejos de vivienda pública y dinámicas destructivas de "competición a la baja" inter-urbana por empleos e inversiones competencia inter-urbana global para el empleo y la

11 Drainville, 2004, p. 6.

12 Perreault y Martin, 2005. 'planetary neoliberalism'11 has taken hold here. Over time, and notwithstanding more recent leftward shifts, Latin American governments have rolled back citizen's protections from market forces and rolled out privatisation, deregulation and liberalisation reforms, often imposed under the wider architecture of IMF and World Bank structural adjustment programs that tied aid and debt deals to the globalisation project ${ }^{12}$. At the urban scale, neoliberalism has unfurled a 'creative destructive' process to reclaim cities as central sites for financial capital accumulation and elite consumption through promoting privatisation and marketisation of public services and infrastructure, gated mega-development projects and the deliberate urban peripheralisation of public housing schemes and the destructive raceto-the-bottom dynamics of global inter-urban competition for jobs and investment $t^{13}$. These "new urban enclosures"14 are orchestrated by a variety of neoliberal urban policy recipes, travelling around the world through different means of policy mobility ${ }^{15}$. In this context, gentrificationled restructuring of Latin American cities has to be seen as part of planetary neoliberalism's urban endgame - to build the city of monopoly rent

\footnotetext{
11 Drainville, 2004, p. 6.

12 Perreault and Martin, 2005.

13 See Janoschka, Sequera and Salinas, 2014.

14 Hodkinson, 2012.

15 González, 2010.
} 
inversión ${ }^{13}$. Estos "nuevos cerramientos urbanos"14 son orquestados por una variedad de recetas de políticas urbanas neoliberales, que circulan por todo el mundo a través de varios canales de movilidad e intercambio de políticas públicas ${ }^{15}$. En este contexto, tenemos que entender la reestructuración de las ciudades de América Latina inducida por la gentrificación, como parte del objetivo del neoliberalismo planetario urbano -la construcción de la ciudad del monopolio de la captación de renta por parte de una clase terrateniente cada vez más global $^{16}$. El resultado es la continua mercantilización del espacio público y la creación de nuevos espacios urbanos, exclusivos para el consumo de las élites en el que las poblaciones excedentes con valor de mercado insuficiente -ya sea trabajadores o consumidores- han de ser expulsados en sigilo o por la fuerza. La gentrificación, por lo tanto, genera nuevos patrones de segregación socio-espacial en sociedades que ya son desiguales, re-agrupando a la población en base a sus ingresos, así como a la identidad social ${ }^{17}$.

El desplazamiento en las ciudades puede iniciarse de varias formas y tomar diversas formas. Puede ser directo, es decir, forzoso e impuesto a los hogares a través de medios violentos como desalojos

13 Véase Janoschka, Sequera y Salinas 2014.

14 Hodkinson, 2012.

15 González, 2010.

16 Charnock, Purcell y Ribera-Fumaz, 2014.

17 Atkinson, 2006. capture for an increasingly global landlord class ${ }^{16}$. The result is the ongoing commodification of public space and the creation of new, exclusive urban spaces of elite consumption in which those surplus populations with insufficient market value - either as workers or consumers - are to be expelled by stealth or force. Gentrification thus generates new patterns of socio-spatial segregation in already highly unequal societies, as groups re-cluster based on their income, as well as social identity $y^{17}$.

Displacement in cities of can be initiated in various ways and take varying forms. It may be direct, i.e. imposed on households through violent means of evictions and foreclosures; or indirect, linked to broader economic and social forces that cause displacement such as neighbourhood change ${ }^{18}$. It may take an exclusionary form, i.e.by preventing poorer households to move into homes in areas promoted to gentrifiers or made empty for speculative abandonment from lastresident or chain displacement within the area ${ }^{19}$. Displacement may be driven by mega-development projects promoting gentrification in erasing whole towns and villages from the world $\operatorname{map}^{20}$ or by military projects to serve place pacification also in

Charnock, Purcell and Ribera-Fumaz, 2014.

Atkinson, 2006.

lbíd.

For a detailed elaboration see Marcuse, 1985; Slater 2009.

Lees, Shin y López, 2016. 
y embargos; o indirecto, vinculado a las fuerzas económicas y sociales más amplias que producen cambios tan profundos en los barrios que los residentes no pueden permitirse ya vivir ahí o no se identifican ya con su lugar de residencia ${ }^{18}$. El desplazamiento también puede entenderse de forma más sutil como un proceso excluyente donde los hogares más pobres son excluidos de zonas destinadas a nuevos residentes de ingresos más altos. También se entiende por desplazamiento el abandono especulativo de vivienda y el desplazamiento en cadena de varios residentes ${ }^{19}$. El desplazamiento puede ser impulsado por mega-proyectos de desarrollo que promueven la gentrificación para borrar del mapa pueblos y aldeas enteros ${ }^{20}$ o por proyectos militares que persiguen la pacificación de barrios (véase favelas en Brasil) que allana su gentrificación posterior ${ }^{21}$. El desplazamiento también puede ser el resultado de los actores urbanos globales, como los fondos de inversión que compran activos en problemas, recuperan las viviendas y desplazan los hogares mientras suben los alquileres y los precios de las casas locales ${ }^{22}$; o actores culturales globales (por ejemplo, UNESCO, las Naciones Unidas) que, en colaboración con los gobiernos nacionales y supranacionales (por

Ibíd., 2006.

Para una elaboración detallada ver Marcuse, 1985; Slater 2009. Lees, Shin y López, 2016.

Janoschka, Sequera y Salinas, 2014.

Beswick, Alexandri, Byrne, Vives-Miró, Fields, Hodkinson y Janoschka, 2016; Hyra, 2015. the interests of gentrification ${ }^{21}$. Displacement can also be the outcome of global urban actors, such as hedge funds that buy distressed assets, repossess homes and displace households while driving up rents and local house prices ${ }^{22}$; or global cultural actors (e.g. UNESCO, United Nations) that in collaboration with national and supranational governments (e.g. the EU) list city centres or urban cultures as architecturally valuable or international heritage sites, creating rent gaps that in turn displace the local population. In each case, the violent logic of dispossession seeks to further reassert space and impose a better off subject ${ }^{23}$. The act of displacement equates to a social injustice that encumbers certain groups from the right to stay put, from the actual right to the city ${ }^{24}$, while at the same time re-writes the history of place, eradicating the voices of economic and political vulnerability, imposing the spatial order of the capital and the ruling classes.

In important respects, therefore, these logics of displacement under the neoliberalisation of Latin American cities are nothing new - they are in fact immanent to capitalist urbanism and the periodic restructuring of cities so lucidly

21 Janoschka, Sequera and Salinas, 2014.

22 Beswick, Alexandri, Byrne, Vives-Miró, Fields, Hodkinson and Janoschka, 2016; Hyra, 2015.

23 Butler and Athanasiou, 2013.

24 Janoschka and Sequera, 2016. 
ejemplo, la UE) declaran centros urbanos o prácticas urbanas como de interés patrimonial o arquitectónico creando brechas de renta que a su vez pueden llegar a desplazar a la población local. En cada uno de estos tipos de desplazamiento, la lógica violenta de despojo reclama aún más espacio e imponer sujetos de mayores recursos ${ }^{23}$. El acto de desplazamiento equivale a una injusticia social que impide a determinados grupos a defender su derecho a quedarse, su mismo derecho a la ciu$\mathrm{dad}^{24}$, mientras que al mismo tiempo re-escribe la historia del lugar, erradicando las voces vulnerables económicamente y políticamente, imponiendo en su lugar el orden espacial del capital y las clases dominantes.

En muchos aspectos estas lógicas de desplazamiento relacionadas con la neoliberalización de las ciudades de América Latina no son nada nuevo,en realidad son inmanentes al urbanismo capitalista y la reestructuración periódica de ciudades tan lúcidamente narradas por Engels en su obra Contribución al problema de la vivienda más de 140 años atrás ${ }^{25}$. Pero así como la gentrificación ha sido teóricamente desarrollada ${ }^{26}$ epistemológicamente cuestionada ${ }^{27}$ y geográficamente matizada con el

23 Butler y Athanasiou, 2013.

24 Janoschka y Sequera, 2016.

25 Engels, 1997.

26 Smith, 2002

27 Ver Sabatini, Sarella y Vásquez, 2008. narrated by Engels in his polemic on The Housing Question more than 140 years ago ${ }^{25}$. But just as gentrification has been theoretically developed $^{26}$ epistemologically questioned ${ }^{27}$ and geographically nuanced over time ${ }^{28}$, so too must our understanding of displacement when utilized in the Latin American context. This special issue responds to this agenda by specifically focusing on the relationship between urban transformation, gentrification and displacement in different cities of Latin America. By attending to Latin American spatialities, the authors help shed light on the new processes of spatial and social expulsion which arise in the current phase of neoliberalism.

The contributors of this special issue are all members of the Contested_cities network, a collective project of researchers across Latin America and Europe funded by the European Union between 2012 and 2016 whose work has focused on processes of dispossession and displacement, expulsion and gentrification. Our work within this network has aimed at extending and deepening our understanding of gentrification beyond its effects on housing, expanding to also cover other land uses (eg retail, public space) and broader

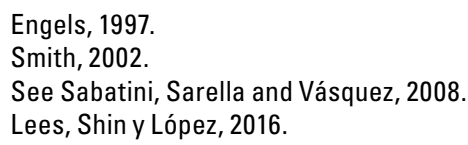


tiempo ${ }^{28}$, también debe hacerlo nuestra comprensión de desplazamiento cuando se utiliza en el contexto latinoamericano. Este número especial responde a esta agenda, centrándose específicamente en la relación entre la transformación urbana, gentrificación y el desplazamiento en diferentes ciudades de América Latina. Al centrarse en las espacialidades de América Latina, los autores contribuyen a arrojar luz sobre los nuevos procesos de expulsión espacial y social que están teniendo lugar en la fase actual del neoliberalismo.

Los colaboradores de este número especial son miembros de la red Contested Cities, un proyecto colectivo de investigadores en toda América Latina y Europa y financiados por la Unión Europea entre 2012 y 2016, cuyo trabajo se ha centrado en los procesos de despojo y el desplazamiento, la expulsión y la gentrificación. Nuestro trabajo dentro de esta red se ha destinado a ampliar y profundizar nuestra comprensión de la gentrificación más allá de sus efectos sobre la vivienda, abarcando también otros usos del suelo (por ejemplo, venta al por menor, el espacio público) y escalas más amplias (desde la calle, al barrio, al distrito y a toda la ciudad), el cambio de las relaciones sociales; y de forma más general la transformación de la vida urbana mediante la imposición de los intereses del capital y la estética de las clases altas. Nuestra agenda de investigación colectiva se ha basado en

28 Lees, Shin y López, 2016. scales (from the street, to the neighbourhood, to the city district and to the whole town), changing social relations; and actually transforming urban living by imposing the capital interests and the aesthetics -shaped by capital- of the upper classes. Our collective research has pushed for a research agenda to specify and politicize the variegation of displacement (expulsion, dispossession, removal, loss of centrality; physical, symbolic, cultural, economic, psychological) and emphasise its interconnection to gentrification. If displacement is conceptualised as a focal point of analysis, then it serves as a chief analytical tool to further politicise anti-gentrification gestures in Latin American cities. In fact in our work we have stressed the importance of paying more attention to the variety of forms of resistance to gentrification and displacement that take place every day in Latin American cities ${ }^{29}$.

Adhering to this call, this special issue aims to bring together the knowledge, concepts, theories, and evidence on displacement that already exists in various disciplines, places and languages. The first two papers by Janoschka, Blanco and Apaolaza offer theoretical conceptualisations over the violence of displacement and the various, often hidden, forms it takes in Latin American cities. We can distinguish at least four analytical

29 González, 2016. 
la delineación y también politización de las formas variadas de desplazamiento (expulsión, despojo, extracción, la pérdida de centralidad; un proceso físico, simbólico, cultural, económico, psicológico) y en el hacer hincapié en su interconexión con la gentrificación. Si el desplazamiento es conceptualizado como un punto focal de análisis, entonces sirve como una herramienta analítica principal para politizar las iniciativas de anti-gentrificación presentes en las ciudades de América Latina. De hecho, en nuestro trabajo hemos hecho hincapié en la importancia de prestar más atención a la variedad de formas de resistencia a la gentrificación y los desplazamientos que tienen cotidianamente en las ciudades de América Latina ${ }^{29}$.

Respondiendo a esta agenda de investigación, este número especial tiene como objetivo el conectar el conocimiento, conceptos, teorías, y casos de estudio sobre desplazamiento que existen en diversas disciplinas, lugares e idiomas. Los dos primeros trabajos de Janoschka, Blanco y Apaolaza ofrecen conceptualizaciones teóricas sobre la violencia del desplazamiento y las diferentes, a menudo ocultas, formas que adopta en las ciudades de América Latina. Podemos distinguir al menos cuatro hilos analíticos: la violencia simbólica relacionada con la re-apropiación del patrimonio cultural y arquitectónico; la violencia en la expulsión de las actividades informales que sirven para "limpiar y

González, 2016. threads here: the symbolic violence related to the re-appropriation of the cultural and architectural heritage; violence in the expulsion of informal activities that serve to 'clean and sanitize' the city and formalize control over the new forms of urbanity that emerge; the violence of the role of different forms of capital (real estate, commercial, symbolic) in urban reconfiguration, an active and decisive role played by investment processes of real estate assets; and the role of government in preparing the ground for and execute the movement, especially when it comes to violence arising from the re-structuring of the housing market. This theoretical approach is further supported by empirical evidence on dispossession, offered by the following two case-study papers on displacement in Mexico City and gentrification in Quito. The third part of the special issue links to the ideological realm - how policy discourses (speeches, materials, laws, tools) are constructed and mobilised, including from elsewhere through policy mobilities, to legitimize practices of displacement by various stakeholders (State, social organizations, private actors) and also the legitimacy of people's right to stay put.

As Michael Janoschka indicates in the first chapter of this issue, displacement is linked to state policies or strategic disregards that emphasise spatial dispossession. Gentrification implications 
desinfectar" la ciudad y formalizar el control sobre las nuevas formas de urbanidad que emergen; la violencia del papel de las diferentes formas de capital (bienes raíces, comercial, simbólica) de reconfiguración urbana y el papel activo y decisivo que juegan los procesos de inversión de bienes inmobiliarios; y el rol del gobierno en la preparación del terreno, sobre todo cuando se trata de la violencia derivada de la reestructuración del mercado de la vivienda. Este enfoque teórico se ve apoyado por la evidencia empírica que se ofrece en los dos estudios de caso sobre los desplazamientos en la Ciudad de México y la gentrificación en Quito. La tercera parte de este dossier especial hace referencia a la esfera ideológica: la forma (discursos, materiales, leyes, herramientas) en que se construyen y movilizan los discursos políticos, incluso prestados de otros lugares a través de los canales de circulación de políticas públicas, legitimando las prácticas de desplazamiento inducidas por una variedad de actores (Estado, organizaciones sociales, actores privados). Por otro lado también existen discursos que ayudan a legitimar el derecho de las personas a permanecer en la ciudad.

Como Michael Janoschka indica en el primer capítulo de este número, el desplazamiento está vinculado a las políticas estatales o las omisiones estratégicas que precipitan el despojo espacial. Las consecuencias de la gentrificación en el desplazamiento cultural, simbólico, económico, psicológico y político apuntan a los principales retos para of cultural, symbolic, economic, psychological and political displacement pinpoint to the major challenges posed for future spatial configuration and social justice in Latin American cities. His pioneering conceptualisation of displacement through the lenses of cultural, symbolic, economic and political and psychological sphere requires a broader encompassing of the political economy of gentrification and displacement, as well as the reference to pronounced interconnectedness of the various forms of displacements.

The second paper of this special issue offers a comprehensive survey of the way in which the concept of displacement is used across the human geography discipline. The work of Jorge Blanco and Ricardo Apaolaza shows the broad meaning that the term displacement can take in Spanish speaking research from voluntary migration and transport mobility to forceful displacement in urban and rural settings. Their aim is to situate the concept of gentrification within this broad research field and show how gentrification creates new forms of displacement triggered by what they call "unjust usurpation of urban centralities".

In the third paper, Victor Delgadillo, elaborates with the various processes of gentrification, critically reflecting on the policies that produced exclusive zones for the middle and the upper classes in the city of Mexico. Interestingly he 
las configuraciones espaciales futuras y la justicia social en las ciudades de América Latina. Su conceptualización pionera de desplazamiento a través de las lentes de ámbito cultural, simbólica, económica y política y psicológica sería aún más poderosa si abarcase una política económica de la ciudad más amplia.

El segundo artículo de este número especial de Blanco y Apaolaza ofrece una revisión bibliográfica de los usos y significados del concepto de desplazamiento a través de la disciplina de la geografía humana. Su trabajo muestra el amplio significado que el término de desplazamiento puede tener en la investigación de habla española desde la migración voluntaria y movilidad en relación al transporte, hasta el desplazamiento forzoso en los entornos urbanos y rurales. Su objetivo es situar el concepto de gentrificación dentro de este campo de investigación amplio y mostrar cómo la gentrificación crea nuevas formas de desplazamiento provocadas por lo que ellos llaman "usurpación injusta de centralidades urbanas".

En el tercer artículo, Víctor Delgadillo, trabaja con las diferentes formas de gentrificación y desplazamiento, valorando críticamente las políticas públicas en la ciudad de México que han producido zonas exclusivas para las clases medias y altas. Es interesante cómo las políticas estatales de promoción de la sostenibilidad urbana, como la densificación y la re-urbanización para frenar décadas shows how sustainable state urban policies such as densification and re-urbanisation to curb decades of urban sprawl have led to profound residential changes in central areas, which are becoming unaffordable for many residents. State policies therefore, implemented strategically through time, had multiple rationales: the satisfaction the elites' interests; the creation of space for real estate profits; the expansion of gentrification frontier through sustainable policies of the compact city; and the expulsion of the vulnerable population towards the periphery.

In the fourth paper of this special issue, Marc Martí, Gustavo Durán and Alejandra Marulanda present an innovative method to study urban transformation processes in Quito (Ecuador) through the construction of a gentrification index. An important finding is how processes of new peripheral area colonisation are leading to the displacement of previous rural uses and users.

Shifting our attention to the mechanisms of housing privatisation, Walter Imilan, Patricia Olivera and Joe Beswick present a comparative study of neoliberalising housing policies on both sides of the Atlantic (Santiago de Chile, Mexico City and London). Neoliberal deregulation eventually reshaped housing policies, providing incentives for homeownership. This long-term housing strategy, evolved into expulsion of the vulnerable 
de expansión desenfrenada, han dado lugar a profundos cambios residenciales en las áreas centrales que se vuelven inasequible para sus residentes. Políticas de Estado, por lo tanto, estratégicamente implementadas con una variedad de objetivos estratégicos: la satisfacción de los intereses de las élites; la creación de espacios especulativos inmobiliarios; la expansión de la frontera de gentrificación a través de políticas sostenibles de la ciudad compacta; y la expulsión de la población vulnerable hacia la periferia.

En el cuarto artículo de este número especial, Marc Martí, Gustavo Durán y Alejandra Marulanda presentan un método innovador para estudiar los procesos de transformación urbana en Quito (Ecuador) a través de la construcción de un índice de gentrificación. Un hallazgo importante es cómo los procesos de nueva colonización en zonas periféricas están abocando al desplazamiento de usos rurales y familias agricultoras.

Prestando ahora atención a los mecanismos de privatización de la vivienda, Walter Imilan, Patricia Olivera y Joe Beswick presentan un estudio comparativo de las políticas de vivienda neoliberalizadoras en ambos lados del Atlántico (Santiago de Chile, Ciudad de México y Londres). La desregulación neoliberal, ha reformado paulatinamente las políticas de vivienda, proporcionando incentivos a la propiedad privada. Esta estrategia, a largo plazo, populations from the city centre, and recreation of centrality for the affluent classes.

The following paper elaborates with an in depth historiography of the variegated forms of displacement of the urban poor in the last 40 years Buenos Aires. Felipe Ignacio Ochsenius Recabarren, Maria Carman, Vanina Lekerman and Marina Wertheimer give a detailed account of policies ranging from direct expulsion of thousands of villeros (informal urban dwellers), to "pedagogical" and symbolic evictions to tolerance towards informal housing and incremental erosion of social housing.

The last contribution of this special issue calls for a planetary conceptualisation of gentrification linking the various geographies of displacement and gentrification. Ernesto López, building on the argument of Brenner and Schmid ${ }^{30}$ on planetary urbanism, claims that the theory of gentrification is a useful tool to understand unevenness at a planetary level. Planetary gentrification exposes the increased aggressiveness of the political and financial power of neoliberalism.

The papers in this special issue make fundamental analytical and methodological innovations towards the study of urban transformation processes in Latin American cities but they also

30 Brenner and Schmid, 2015. 
ha resultado en la expulsión de las poblaciones vulnerables desde el centro de la ciudad a la periferia, y la recreación de la centralidad para las clases acomodadas.

El siguiente artículo contribuye con una historiografía de las variadas formas de desplazamiento que han sufrido los pobres urbanos en los últimos 40 años en Buenos Aires. Felipe Ignacio Ochsenius Recabarren, María Carman, Vanina Lekerman y Marina Wertheimer aportan un análisis detallado de políticas públicas que van desde la expulsión directa de miles de villeros (habitantes de barrios informales), a desalojos "pedagógicos" y simbólicos, la tolerancia hacia la vivienda informal y la erosión gradual de vivienda social.

La última contribución de este número especial ofrece una conceptualización planetaria de la gentrificación que conecta las diferentes geografías de desplazamiento y gentrificación. Ernesto López, basándose en la hipótesis de Brenner y Schmid ${ }^{30}$ sobre el urbanismo planetario, afirma que la teoría de la gentrificación es una herramienta útil para comprender las el desarrollo desigual del capitalismo a nivel planetario. La gentrificación planetaria expone el aumento de la agresividad del poder político y económico del neoliberalismo.

Los artículos de este número especial contribuyen con innovaciones analíticas y metodológicas

Brenner y Schmid, 2015 raise questions about limitations and point towards future research agendas. Conceptually, authors in this special issue use different conceptions of the term displacement and its relationship to gentrification. Martí et al, for example, identify gentrification without displacement in Quito while Janoschka understands displacement as inherent to gentrification. Methodologically, there is also tension between case study-led research and contributions that aim to have global reach. City specific studies such as those on Quito, Mexico City and Buenos Aires present difficulties when it comes to generate theoretical learnings. More work could be done, for example, to understand whether events such as the "pedagogical evictions" in Buenos Aires are taking place in other cities or whether the gentrification index for Quito is applicable elsewhere. At the other extreme, concepts such as "planetary gentrifications" advanced by LópezMorales can obfuscate the specific historical, political, economic, social and urban context of the variegated nature of gentrification. Within the Contested Cities network we have tried to balance these tensions by developing a comparativist agenda such as that advanced in this special issue by Janoschka and Imilan et al, which is still emerging. 
fundamentales hacia el estudio de los procesos de transformación urbana en las ciudades de América Latina, pero también plantean limitaciones de estudio y apuntan a futuras agendas de investigación. Conceptualmente, los autores de este número especial utilizan diferentes concepciones del término desplazamiento y su relación con la gentrificación. Martí et al, por ejemplo, identifican procesos de gentrificación sin desplazamiento en Quito, mientras que la conceptualización de Janoschka desplazamiento es algo inherente a la gentrificación. Metodológicamente, también hay tensión entre las investigaciones de caso y aquellas aportaciones que pretenden tener un alcance global. Los estudios específicos de ciudades tales como Quito, Ciudad de México y Buenos Aires presentan dificultades cuando se trata de generar aprendizajes teóricos. Sería interesante entender, por ejemplo, si los "desalojos pedagógicos" que identifican las autoras en Buenos Aires tienen lugar también en otras ciudades o si el índice de gentrificación de Quito es aplicable a otros lugares. En el otro extremo, conceptos tales como "gentrificación planetaria" presentados por López-Morales puede ofuscar el contexto histórico, político, económico, social y urbano específico de la naturaleza variada de gentrificación. Dentro de la red Contested Cities hemos tratado de equilibrar estas tensiones mediante el desarrollo de una agenda comparativista como la avanzada en este número especial por Janoschka e Imilan et al, que todavía está emergiendo.
Gentrification is an unjust social praxis that imposes the interests of capital, the elites and the ruling classes in space. In the case of Latin America, the different temporalities and velocities of gentrification indicate the various rhythms of dispossession. The end result is the creation of homogenous and hygienic gentrified spaces, cleansed from any kind of diversity that does not collide with the middle classes dispositions. The other side of the story again remains the dispossession of the poor and the vulnerable population and its expulsion to the periphery of the city. This kind of dynamic segregation and the practice of making invisible of the vulnerable social classes does not necessarily make space a better place. On the contrary, the encouragement of unjust spatial practices creates new dynamics of implosion or explosion to be confronted by the gentrified city. 
Gentrificación es una praxis social injusta que impone los intereses del capital, las élites y las clases dominantes en el espacio. En el caso de América Latina, las diferentes temporalidades y velocidades de la gentrificación indican los distintos ritmos de despojo. El resultado final es la creación de espacios aburguesados homogéneos e higienizados, carentes de diversidad para no entrar en conflicto con las demandas de clases medias. En contraste a estos paisajes seguimos encontrándonos con el despojo de los pobres y la población vulnerable y su expulsión a la periferia de la ciudad. Este tipo de segregación dinámica y la práctica de hacer invisible a las clases sociales vulnerables no significa que la ciudad sea mejor. Por el contrario, el fomento de las prácticas espaciales injustas crea nuevas dinámicas de implosión urbana que se recrean en la ciudad aburguesada.

\section{Bibliografía}

ANDREß, Hans-Jürgen, ed. y LOHMANN, Henning, ed. The Working Poor in Europe: Employment, Poverty and Globalization. Cheltenham, UK, Edward Elgar. 2008.

ATKINSON, Rowland. Padding the bunker: strategies of middle-class disaffiliation and colonisation in the city. Urban Studies. 43(4): 819-832, 2006. DOI 10.1080/00420980600597806.

BESWICK, Joe; ALEXANDRI, Georgia; BYRNE, Michael; VIVES-MIRÓ, Sònia; FIELDS, Desiree;
HODKINSON, Stuart y JANOSCHKA, Michael. Speculating on London's housing future: The rise of global corporate landlords in 'post-crisis' urban landscapes. City. 20(2): 321-341, 2016. DOI 10.1080/13604813.2016.1145946.

BRENNER, Neil, y SCHMID, Christian. Towards a new epistemology of the urban? City. 19(2-3): 151-182, 2015. DOI 10.1080/13604813.2015.1014712.

BUTLER, Judith y ATHANASIOU, Athena. Dispossession: The performative in the political. Cambridge, Polity Press. 2013.

CABRERA PACHECO, Ana. Primitive accumulation in indigenous Mexico: the contested transformation of the Maya Solar of Yucatán. City. In press.

CHARNOCK, Greig, PURCELL, Thomas F. y RIBERA-FUMAZ, Ramon. City of Rents: the Limits to the Barcelona model of urban competitiveness. International Journal of Urban and Regional Research. 38(1): 198-217, 2014. DOI 10.1111/1468-2427.12103.

CLARK, Eric. The Order and simplicity of gentrification - a political challenge. En: ATKINSON, Rowland, ed. y BRIDGE, Gary, ed. Gentrification in a global context: the new urban colonialism. London, Routlege. 2005. p. 256-264.

DRAINVILLE, André C. Contesting Globalization: Space and Place in the World Economy. London, Routledge. 2004.

ENGELS, Friedrich. The housing question. Moscow, Progress Publishers. 1997. 
GONZÁLEZ, Sara. Looking comparatively at displacement and resistance to gentrification in Latin American cities. Urban Geography. 2016. DOI 10.1080/02723638.2016.1200337.

--- Bilbao and Barcelona 'in motion'. How urban regeneration 'models' travel and mutate in the global flows of policy tourism. Urban Studies. 48(7): 1397141, 2011. DOI 10.1177/0042098010374510.

HALL, Derek. Primitive accumulation, accumulation by dispossession and the global land grab. Third World Quarterly. 34(9): 1582-1604, 2013. DOI $10.1080 / 01436597.2013 .843854$.

HERZOG, Lawrence A. Global Suburbs: Urban Sprawl from the Rio Grande to Rio de Janeiro. New York, Routledge. 2015.

HIDALG0, Rodrigo, ed. y JANOSCHKA, Michael, ed. La ciudad neoliberal. Gentrificación y exclusión en Santiago de Chile, Buenos Aires, Ciudad de México y Madrid. Santiago de Chile, Pontificia Universidad Católica de Chile. 2014.

HODKINSON, Stuart. The new urban enclosures. City. 16(5): 500-518, 2012. DOI 10.1080/13604813.2012.709403.

HYRA, Derek. The back-to-the-city movement: Neighbourhood redevelopment and processes of political and cultural displacement. Urban Studies. 52(10): 1753-1773, 2015. DOI 10.1177/0042098014539403.

JANOSCHKA, Michael y SEQUERA, Jorge. Gentrification in Latin America: addressing the politics and geographies of displacement. Urban Geography. 2016. DOI 10.1080/02723638.2015.1103995.

JANOSCHKA, Michael; SEQUERA, Jorge y SALINAS, Luis. Gentrification in Spain and Latin Ameri$\mathrm{ca}$ - a Critical Dialogue. International Journal of Urban and Regional Research. 38(4): 1234-1265, 2014. DOI 10.1111/1468-2427.12030.

KOTHARI, Miloon. The Global Crisis of Displacement and Evictions: a Housing and Land Rights Response. New York, Rosa Luxemburg Stiftung. 2015.

LEES, Loretta, SHIN, Hyun Bang y LÓPEZ MORALES, Ernesto. Planetary Gentrification. Cambridge, Polity Press. 2016. ISBN: 978-0-7456-7165-9.

MARCUSE, Peter. Gentrification, abandonment and displacement. Connection, causes and policy responses in New York City. [En línea]. Journal of urban and contemporary law. 28: 195-240, 1985. Disponible en: http://openscholarship.wustl.edu/ law_urbanlaw/vol28/iss1/4.

PERREAULT, Thomas y MARTIN, Patricia. Geographies of neoliberalism in Latin America. Environment and Planning A. 37(2): 191-201, 2005. DOI 10.1068/a37394.

SABATINI, Francisco; SARELLA, María y VÁSQUEZ, Héctor. Gentrificación sin expulsión, o la ciudad latinoamericana en una encrucijada histórica. Revista 180. (24): 18-25, 2008.

SASSEN, Saskia. Expulsions: brutality and complexity in the global economy. Cambridge, Massachusetts, 
The Belknap Press of Harvard University Press. 2014.

SLATER, Tom. Missing Marcuse: on gentrification and displacement. City. 13(2-3): 292-311, 2009. DOI $10.1080 / 13604810902982250$.

SMITH, Neil. New Globalism, New Urbanism: Gentrification as Global Urban Strategy. Antipode. 34(3): 427-450, 2002. DOI 10.1111/1467-8330.00249. 